\title{
Coaches' and referees' opinion about the influence of intellectual impairment on fundamental basketball activities
}

\author{
Javier PÉREZ-TEJERO, Ignacio POLO-MÁS, Javier PINILLA-ÁRBEX \\ and Javier COTERÓN-LÓPEZ
}

Faculty of Physical Activity and Sport Sciences (INEF). Technical University of Madrid (UPM)

(Received on February 8, 2017; Accepted on 10 May, 2017)

\begin{abstract}
One of the major problems that basketball for players with intellectual impairment (II) is facing nowadays is the lack of evidence-based eligibility systems which ensures that only athletes with significant limitations performing basketball participate in II-competitions. Moreover, to solve this situation is needed to re-include this sport in the Paralympic Program. A first step to develop these systems is to investigate how II influences basketball performance. Due to this, the purpose of this study was to analyze experienced II-basketball coaches' and referees' opinion about how II impact on fundamental basketball activities. 40 coaches and 6 referees from different levels of II-competition completed a questionnaire designed "ad hoc" to assess their opinion about the influence of II on fundamental basketball activities. Participants expressed that II-players present limitations to carry out the $92.68 \%$ of the activities from the questionnaire. Mean values of offensive individual tactics were significantly higher than technical skills and defensive individual tactics. These results indicated that IIplayers present limitations performing basketball and they are relevant to orientate future research to develop evidence-based eligibility systems in this sport.
\end{abstract}

Keywords: Paralympic sport, eligibility systems, classification.

La opinión de los entrenadores y árbitros sobre la influencia de la discapacidad intelectual en las actividades fundamentales del baloncesto

RESUMEN: Uno de los principales problemas a los que se enfrenta actualmente el baloncesto para personas con discapacidad intelectual (DI) es la falta de sistemas de elegibilidad basados en la evidencia que aseguren que sólo deportistas con limitaciones significativas para practicar baloncesto participan en competiciones específicas. Por otra parte, se hace necesario resolver dicha situación para reincluir esta modalidad como deporte paralímpico. Un primer paso para desarrollar estos sistemas es investigar cómo influye la DI en la práctica del baloncesto. Debido a ello, el objetivo de este estudio fue analizar la opinión de entrenadores y árbitros con experiencia en DI sobre cómo la DI influye en las actividades fundamentales del baloncesto. 40 entrenadores y 6 árbitros completaron el cuestionario diseñado "ad hoc" para evaluar su opinión sobre la influencia de la DI en las actividades fundamentales en baloncesto. Los participantes expresaron que los jugadores con DI presentan limitaciones para llevar a cabo el $92.68 \%$ de las actividades expresadas en el cuestionario. Los valores de táctica individual ofensiva fueron significativamente mayores que los de habilidades técnicas y táctica individual defensiva. Estos resultados indicaron que los jugadores con DI presentan limitaciones practicando 
baloncesto y son relevantes para orientar investigaciones futuras para el desarrollo de sistemas de elegibilidad basados en la evidencia en este deporte.

Palabras clave: Deporte paralímpico, sistemas de elegibilidad, clasificación

Correspondencia: Mr. Javier Pérez Tejero, Faculty of Physical Activity and Sport Sciences (INEF). Technical University of Madrid (UPM). C/ Martín Fierro, 7, 28040, Madrid. Telephone number: +34 9133641 40. Email: j.perez@upm.es

\section{Introduction}

Basketball for players with intellectual impairment (II) is one of the most practiced team sport in this population at high level competition (INAS, 2015). It has been demonstrated in the literature that participation in this sport can provide II-players benefits on fitness (Stanisic, Kocic, Aleksandrovic, Stankovic, \& Radovanovic, 2012; Tsimaras, Samara, Kotzamanidou, Bassa, Fotiadou, \& Kotzamanidis, 2009), motor skills acquisition (Franciosi, Gallotta, Baldari, Emerenziani, \& Guidetti, 2012; Alsasua, 2012) and social development (Stanišić, 2012). Due to these benefits, it seems necessary to continue promoting this sport in this population worldwide.

II-sports at high level competition lived an important growth during the 90s, being II-sports included in the Paralympic Games in Athens 1996 (Steadward, Watkinson, \& Wheeler, 2003). IIbasketball was included in Sydney 2000 Paralympic Games; however, during these competitions, it was detected that 10 of the 12 basketball players from the gold winning medal team cheated the eligibility process at that moment and they did not present any impairment. Immediately it was discovered, the International Paralympic Committee (IPC) announced that, due to serious difficulties in determining the eligibility of athletes, II-sports were suspended from the Paralympic Program (Burns, 2015). In 2007, the IPC endorsed a new classification system to ensure equity by minimizing the role that impairment plays on final outcome during competition (Tweedy \& Vanlandewijck, 2011). These systems must be adopted and customized for application in all sports throughout the movement. To develop these systems for II-athletes, and in order to re-include II-sports in the Paralympic Program, the International Federation for Sports for Para-athletes with Intellectual Disabilities (INAS) and IPC worked together during the last years in a large multidisciplinary research project (Van Biesen, Mactavish, Pattyn, \& Vanlandewijck, 2012). Thanks to the development of these systems in table-tennis, swimming and athletics, these three sports were re-included in London 2012 Paralympic Games with the participation of 118 II-athletes.

At this moment, eligibility systems for II-basketball are under development (Pérez-Tejero, Pinilla, \& Vanlandewijck, 2015; Pinilla, Pérez-Tejero, Van Biesen, \& Vanlandewijck, 2015; Pinilla, Pérez-Tejero, Van Biesen, \& Vanlandewijck, 2016; Pinilla, Pérez-Tejero, \& Van Biesen, 2017) and to do this, one necessary step is to investigate the impact of intellectual impairment on basketball performance (Tweedy \& Vanlandewijck, 2011). Different studies in able-bodied (AB) basketball indicated that basketball is a team sport in which environment is constantly changing; consequently, to success in this sport it is dependent on acting and deciding appropriately to the particular circumstances of the game (Araujo \& Esteves, 2009). According to the literature, in these processes intellectual functioning seems to play an important role to recognize each game 
situation (Allard, Graham, \& Paarsalu, 1980) and to process the information successfully (Tenenbaum, 2003). Due to this, it seems that having an impaired intellectual functioning might negatively impact on basketball performance. Pérez et al. (2015) observed that in elite IIbasketball competitions, II-players reached lower shooting effectiveness compared with results from AB-literature. In addition, in this study it seemed that II-players committed more turnovers and made less assists than the compared AB-players in the literature. In line with this study, Pinilla et al. (2015) observed that performance variability in game-related statistics was higher in II-basketball competitions compared with AB-basketball competitions. Authors indicated that probably, differences in the degree of impairment or in the abilities impaired between ID-players could explain the larger variability in this modality. Another study observed that the intellectual quotient (IQ) score correlated positively with the development of four fundamental basketball skills: ball handling, reception, passing and shooting (Guidetti, Franciosi, Emerenziani, Gallotta, $\&$ Baldari, 2007). These studies were relevant to indicate that II seems to negatively affect on basketball performance; however, as authors indicated in these studies, it was needed to investigate how II impact on those fundamental basketball activities.

A recent study compared elite II-players and amateur AB-players' capacity to solve different game situations through a field test. This test included 8 standardized game situations: two 1on-1 situations, two 2-on-1 situations and four 2-on-2 situations that II-players had to play (Pinilla et al; 2016). Results indicated that II-players used more time to decide and to execute the solution than AB-players. Also, they committed more rule infractions, they used more dribbles and they solved fewer situations successfully. Results in this test classified correctly $98.6 \%$ of the sample according to their predicted group or pertinence (II or AB) and confirmed that II-players had significant limitations to solve a basketball game situation as fast and accurate as AB-players. Authors suggested that further research was needed to identify other components of basketball performance that might be negatively influenced by II.

Different studies in AB-basketball have taken into consideration coaches' opinion and experience professionals in the field to investigate the relevance of different topics for basketball development such as: technique, tactics, physical performance and psychology during players' development stage (Nuno, Vaz, Maçãs, \& Sampaio, 2009), rules adaptation in kids (Ortega, Piñar, Salado, Palao, \& Gómez Ruano, 2012), specialization per game position (Ortega, Salado, Gómez Ruano, Palao, \& Piñar, 2011) the kind of game systems that should be used training young players (Ortega, Salado, \& Sainz de Baranda, 2013). Also, the opinion of coaches' and referees' about the importance of the rules at the initiation stage of basketball (Vizcaíno, Almagro, Rebollo, \& Sáenz-López, 2013) and, in line with this study, the coaches' opinion about players' behaviors that can influence basketball performance (Escudero, Balagué, \& García-Mas, 2002). Due to the need to continue investigating how II influences on basketball performance, we considered that it might be relevant to take into account the knowledge of those experienced professionals involved daily in II-basketball to investigate which basketball activities could be more negatively influenced by II. According to this, the purpose of this study was to analyze II-basketball coaches' and referees' opinion about how II impact on fundamental basketball activities. Results from this research could orientate future 
research in the development of II-basketball eligibility systems (Tweedy \& Vanlandewijck, 2011) and might contribute to re-include this modality in the Paralympic Program.

\section{Method}

\section{Design}

A Likert-scale questionnaire was designed "ad hoc" to assess coaches' and referees' opinion about the influence of II on fundamental basketball activities. According to Martín Arribas (2004), items from the questionnaire were elaborated based on the components of the game identified in the literature as relevant to perform in basketball. A first draft of the questionnaire was developed by two basketball experts (more than 10 years of experience). This draft presented a first section related to personal data and a specific section to assess coaches' and referees' opinion. The specific section included 33 items divided in three categories: individual components (17 items), collective components ( 9 items) and contextual components ( 7 items). A 7-point Likert scale was selected to evaluate coaches' and referees' opinion in each item due to the higher variability and higher overall reliability found using this scale instead a 5-point scale in previous studies related with physical activity (Rhodes, Matheson, \& Mark, 2010). This first draft was reviewed independently by 6 basketball experts that met at all of the four following criteria: to have a $\mathrm{PhD}$ related with basketball, to be basketball professor at the University with at least five years of experience, to have the national basketball coach certificate and to have published articles in journals or books related with basketball. As result from experts' feedback, new items considered fundamental performing basketball were included in the questionnaire. In table 1, experts' proposal of modifications is presented.

Table 1. Proposal of changes in the questionnaire according to basketball experts experience.

\begin{tabular}{|c|c|c|}
\hline Section & Experts feedback or items proposed to include & Changes made after feedback \\
\hline Personal data & $\begin{array}{l}\text { Specific impairment academic training should be } \\
\text { included }\end{array}$ & $\begin{array}{l}\text { "Others" as additional option } \\
\text { was included }\end{array}$ \\
\hline \multirow{4}{*}{$\begin{array}{l}\text { Individual } \\
\text { Components }\end{array}$} & To make a jump stop or a stride stop & 2 items were included \\
\hline & To use pivots to orient toward the basket & 1 item was included \\
\hline & $\begin{array}{l}\text { To make a chest or bounce pass depending on the } \\
\text { opponents }\end{array}$ & 1 item was included \\
\hline & $\begin{array}{l}\text { To make a crossover or rocker step depending on the } \\
\text { defender }\end{array}$ & 1 item was included \\
\hline \multirow{4}{*}{$\begin{array}{l}\text { Collective } \\
\text { Components }\end{array}$} & $\begin{array}{l}\text { Feints, passes or shoots should be included in technical } \\
\text { components }\end{array}$ & $\begin{array}{l}\text { It was moved to technical } \\
\text { components }\end{array}$ \\
\hline & To occupy spaces depending on the opponents & 1 item was included \\
\hline & $\begin{array}{l}\text { To include items related to decision making and passing } \\
\text { or shooting }\end{array}$ & 2 items were included \\
\hline & To include defensive components & 7 items were included \\
\hline $\begin{array}{l}\text { Contextual } \\
\text { Components }\end{array}$ & $\begin{array}{l}\text { To include items related with stress in different } \\
\text { situations of the game }\end{array}$ & 5 items were included \\
\hline
\end{tabular}

In addition, basketball experts proposed to re-structure the questionnaire into three sections: personal data, difficulty on fundamental basketball activities and influence of contextual (c) Psy, Soc, \& Educ, 2017, Vol. 9(3) 
components on II-players. After these changes, a final version of the questionnaire was elaborated and it was called "Coaches' opinion about the impact of intellectual impairment on basketball performance" (COEIIB). In this version, coaches had to fill in the first section (personal data) through a multiple choice system. In the second section, coaches and referees had to judge, using a 7-point Likert scale, the degree of difficulty they considered that II-players could have carrying out the activities presented in the different items ( $1=$ extremely easy and $7=$ extremely difficult). In this section, items were grouped into five performance components for basketball: technical skills, motor and skills components, offensive individual tactics, offensive collective tactics and defensive individual tactics. In the third section, coaches and referees had to indicate the degree of agreement with different sentences related with the influence of contextual components on II-players using a 7 -point Likert scale $(1=$ totally disagreement and $7=$ totally agreement). The structure and content of the questionnaire is presented in table 2.

Table 2. Final structure and content of the questionnaire.

\begin{tabular}{|c|c|c|c|}
\hline Section & Performance components & $\begin{array}{c}\mathrm{N}^{\mathrm{er}} \\
\text { items }\end{array}$ & Example \\
\hline 1.Personal data & & 9 & "Sports technical training" \\
\hline \multirow{5}{*}{ 2.Difficulty in the game } & 1. Technical skills & 10 & $\begin{array}{l}\text { "To carry out a jump shot with a proper } \\
\text { technical skill" }\end{array}$ \\
\hline & $\begin{array}{l}\text { 2. Motor and skills } \\
\text { components }\end{array}$ & 4 & $\begin{array}{c}\text { "To carry out activities that require a high } \\
\text { commitment of balance" }\end{array}$ \\
\hline & $\begin{array}{l}\text { 3. Offensive individual } \\
\text { tactics }\end{array}$ & 11 & $\begin{array}{c}\text { "To use a crossover or rocker step depending } \\
\text { on the position of this defender" }\end{array}$ \\
\hline & $\begin{array}{l}\text { 4. Offensive collective } \\
\text { tactics }\end{array}$ & 8 & $\begin{array}{l}\text { "To carry out an indirect pick to generate a } \\
\text { superiority in the game without the ball" }\end{array}$ \\
\hline & $\begin{array}{l}\text { 5. Defensive individual } \\
\text { tactics }\end{array}$ & 8 & $\begin{array}{l}\text { "To locate defensive on the axis } \\
\text { attack/basket" }\end{array}$ \\
\hline $\begin{array}{l}\text { 3.Contextual } \\
\text { components of the game }\end{array}$ & & 12 & $\begin{array}{l}\text { "The presence of the public affects the } \\
\text { player's performance" }\end{array}$ \\
\hline
\end{tabular}

\section{Content validation and reliability}

To guarantee that instrument content was appropriate to answer the research question, expert criteria validation was conducted (García de Yébenes, Rodríguez Salvanés, \& Carmona, 2009). To do this, the last version of the questionnaire was sent independently to each basketball expert that participated in the expert panel in the previous step of the questionnaire design. Experts were asked to accept or to reject each item proposed in the new version of the questionnaire if they considered or not that each item referred to a fundamental basketball activity. Basketball experts presented $100 \%$ agreement for inclusion of all items presented in the last version, so this version was finally accepted for research purposes.

\section{Participants}

The sample was composed of 6 II-basketball referees and 40 II-basketball coaches from different levels of competition that ranged from the highest to the lowest level in the following order: INAS (International competition), competition level, adapted level and ability level. Coaches 
from these competitions except INAS participated in Spanish competitions. Sample, age and experience of all the participants and participants per sub-sample are presented in table 3.

Table 3. Description of the sample in this study.

\begin{tabular}{ccccccc}
\hline & $\begin{array}{c}\text { INAS } \\
(\mathrm{IN})\end{array}$ & $\begin{array}{c}\text { Competition } \\
(\mathrm{COM})\end{array}$ & $\begin{array}{c}\text { Adapted } \\
(\text { ADP })\end{array}$ & $\begin{array}{c}\text { Ability } \\
(\text { ABL })\end{array}$ & $\begin{array}{c}\text { Referees } \\
(\mathrm{REF})\end{array}$ & Total \\
\hline $\mathrm{N}$ & 7 & 16 & 11 & 6 & 6 & 46 \\
Age & 50.1 & 34.5 & 34.9 & 38.17 & 30.83 & 36.98 \\
Experience in II- & $(10.98)$ & $(10.19)$ & $(9.67)$ & $(13.51)$ & $(5.19)$ & $(11.4)$ \\
basketball (years) & $(14.2$ & 6.56 & 7.54 & 8.83 & 1.83 & 8.26 \\
& & $(6.31)$ & $(5.59)$ & $(12.94)$ & $(0.75)$ & $(9.36)$ \\
\hline
\end{tabular}

\section{Test administration}

The questionnaire was administrated through an on-line survey platform (Surveymonkey ${ }^{\circledR}$ ). Participants were called by e-mail to participate in this study. To do this, this study received the collaboration of the International Federation for Para-athletes with Intellectual Disabilities (INAS), the Spanish Federation of Sports for athletes with Intellectual Disability (FEDDI) and the Basketball Federation of Madrid (FBM). In this platform, previously to answer the questionnaire, the instructions and the informed consent were presented. All respondents agreed to freely participate in the study.

\section{Statistical Analysis}

Descriptive statistics (mean and standard deviation) were calculated for each item and performance component. In addition, Shapiro Wilk test was conducted to check normal distribution of the data. To identify the differences between scores obtained in the five performance components analyzed in the section "difficulty in the game", Friedman test was performed to analyze if there were differences between all the components and also U MannWhitney test was performed to analyze the differences between each performance component and the other components separately. In addition, this test was used to identify differences between sub-groups from the sample. Finally, to explore the influence of coaches' and referees' experience on the scores given to each item, a linear regression model was calculated. All statistical analyses were performed using PASW statistics 20 (SPSS; Chicago, IL, USA). Statistical significance was set at $\mathrm{P}<0.05$.

\section{Results}

In table 4, mean values obtained in the different performance component for basketball are presented. It was observed that mean values of offensive individual tactics were significantly higher $(p \leq 0.05)$ than technical skills and defensive individual tactics. These values are also presented per coaches' level of competition and referees, but no significant differences $(p \geq 0.05)$ were found between any of the groups. 
Table 4. Mean values of difficulty identified per basketball performance component and comparison between coaches (per level of competition) and referee' opinions.

\begin{tabular}{lcccccc}
\hline \multicolumn{7}{c}{ Performance components } \\
\hline $\begin{array}{l}\text { Sample and } \\
\text { sub-groups }\end{array}$ & $\begin{array}{c}\text { 1. Technical } \\
\text { skills }\end{array}$ & $\begin{array}{c}\text { 2. Motor and } \\
\text { skills } \\
\text { components }\end{array}$ & $\begin{array}{c}\text { 3. Offensive } \\
\text { individual } \\
\text { tactics }\end{array}$ & $\begin{array}{c}\text { 4. Offensive } \\
\text { collective } \\
\text { tactics }\end{array}$ & $\begin{array}{c}\text { 5. Defensive } \\
\text { individual } \\
\text { tactics }\end{array}$ & Sig. \\
\hline TOTAL (n=46) & $4.29^{*}(0.92)$ & $4.61(0.95)$ & $4.91^{*}(1)$ & $4.56(1.05)$ & $4.35^{*}(1)$ & $3>1,5$ \\
INAS $(\mathrm{n}=7)$ & $3.87(1.07)$ & $4.43(0.73)$ & $4.84(0.87)$ & $4.53(0.83)$ & $4.59(0.92)$ & \\
COMP (n=16) & $4.06(0.98)$ & $4.5(1.14)$ & $4.88(1.08)$ & $4.33(1.68)$ & $4.19(0.99)$ & \\
APT $(\mathrm{n}=11)$ & $4.46(0.69)$ & $4.82(0.72)$ & $5.07(0.83)$ & $4.86(0.96)$ & $4.46(0.98)$ & \\
HAB $(\mathrm{n}=6)$ & $4.37(0.79)$ & $4.75(1.19)$ & $4.79(1.51)$ & $4.58(1.2)$ & $4.33(1.99)$ & \\
REF $(\mathrm{n}=6)$ & $5.03(0.82)$ & $4.62(0.97)$ & $4.89(0.94)$ & $4.58(1.14)$ & $4.29(1.24$ & \\
\hline
\end{tabular}

$* \mathrm{p} \leq 0.05$

The calculated linear regression model to explore the influence of coaches' experience on their opinion was not significant $(\mathrm{p} \leq 0.05)$. It indicated that coaches' opinion was not affected by their experience in years neither level of competition.

In table 5, it is summarized the number of items punctuated by coaches and referees with mean values higher than 4 , indicating that they think that II-players present some limitations in these activities. From all items presented in the questionnaire, $92.68 \%$ of the items received a punctuation higher than 4 .

Table 5. Number of items in each component in which coaches and referees indicated that II-players presented difficulties (item value $>4$ ) or not (item value $<4$ ).

\begin{tabular}{lccc}
\hline \multicolumn{1}{c}{ Performance components } & Number of items & Items' value $>4$ & Items' value $<4$ \\
\hline 1. Technical skills & 10 & 8 & 2 \\
2. Motor and skills components & 4 & 4 & 0 \\
3. Offensive individual tactics & 11 & 11 & 0 \\
4. Offensive collective tactics & 8 & 8 & 0 \\
5. Defensive individual tactics & 8 & 7 & 1 \\
\hline \multicolumn{1}{c}{ TOTAL } & 41 & 38 & 3 \\
\hline
\end{tabular}

The $25 \%$ of the items in which coaches and referees indicated higher difficulties are presented in table 6. 
Table 6. Items in which coaches and referees indicated that II-players presented higher difficulties.

\begin{tabular}{|c|c|c|}
\hline Performance components & Item definition & Score \\
\hline \multirow[b]{2}{*}{ 1. Technical skills } & To carry out a jump shot with a proper technique. & $5.2(1.4)$ \\
\hline & $\begin{array}{l}\text { To dribble, to pass, to receive, to receive it or to shoot } \\
\text { to the basket in long distances with a close defender. }\end{array}$ & $4.9(1.3)$ \\
\hline 2. Motor and skills components & $\begin{array}{c}\text { Carry out in a quick and efficient way activities with } \\
\text { high eye-hand coordination involvement }\end{array}$ & $4.8(0.96)$ \\
\hline \multirow{6}{*}{ 3. Offensive individual tactics } & To identify offensive and defensive game systems & $5.3(1.3)$ \\
\hline & $\begin{array}{l}\text { To carry out an indirect pick to generate a position of } \\
\text { superiority in the game without ball. }\end{array}$ & $5.2(1.4)$ \\
\hline & $\begin{array}{l}\text { To make appropriate technical and tactical decisions } \\
\text { answering in the best way to "where", "when" and } \\
\text { "how" to act depending on the game situation }\end{array}$ & $5.0(1.0)$ \\
\hline & To avoid showing the opponent their intentions & $5.0(1.1)$ \\
\hline & $\begin{array}{l}\text { To memorize and reproduce in the field the } \\
\text { instructions given by the coach }\end{array}$ & $5.0(1.3)$ \\
\hline & To generate space with a partner & $5.0(1.4)$ \\
\hline 4. Offensive collective tactics & $\begin{array}{c}\text { To make a crossover or rocker step depending on the } \\
\text { defender. }\end{array}$ & $5.2(1.3)$ \\
\hline
\end{tabular}

Regarding to the coaches and referees' opinion about the influence of different contextual variables on II-players performing basketball, table 7 presents the means and standard deviations of the punctuation given by the participants in each item. The Likert scale used to assess these items ranged from 1 (totally disagreement) to 7 (totally agreement).

Table 7. Scores obtained in each item related to the influence of contextual factors.

\begin{tabular}{|c|c|c|}
\hline Item & Definition & Score \\
\hline 1 & They have difficulties in social interactions and adaptation with teammates. & $3.3(1.8)$ \\
\hline 2 & $\begin{array}{l}\text { They have more resistance difficulty during the competition than players with no } \\
\text { disability. }\end{array}$ & $5.0(1.5)$ \\
\hline 3 & Faced with a major shot in the match result, they are highly effective response. & $3.7(1.3)$ \\
\hline 4 & $\begin{array}{l}\text { In specific competition for II-players, those with higher cognitive abilities (IQ), get } \\
\text { better results in the match able to reflect in its statistics. }\end{array}$ & $5.3(1.4)$ \\
\hline 5 & $\begin{array}{l}\text { The player with the highest cognitive ability (IQ) has the major physical skill } \\
\text { levels. }\end{array}$ & $4.9(1.6)$ \\
\hline 6 & $\begin{array}{l}\text { They are able to meditate and express why they have carried out an action after } \\
\text { having done it. }\end{array}$ & $4.1(1.3)$ \\
\hline 7 & They understand and make use of the game rules properly. & $4.3(1.2)$ \\
\hline 8 & $\begin{array}{l}\text { Stress during a game tied when the time is short have a negative effect on their } \\
\text { performance. }\end{array}$ & $4.5(1.5)$ \\
\hline 9 & Player's performance can be affected due to the presence of public. & $4.5(1.7)$ \\
\hline 10 & Player's performance can be affected due to playing at home or away. & $4.3(1.5)$ \\
\hline 11 & $\begin{array}{l}\text { They manage properly the stress in an important game (classification, elimination, } \\
\text { end...). }\end{array}$ & $3.8(1.4)$ \\
\hline 12 & $\begin{array}{l}\text { They have difficulties to adapt to a new and unknown game situation (adaptive } \\
\text { behavior) }\end{array}$ & $5(1.11)$ \\
\hline
\end{tabular}




\section{Discussion}

The current study aimed to analyze II-basketball coaches and referees' opinion about how II impact on fundamental basketball activities. In fact, it seems pertinent and relevant to ask coaches opinion about players' performance assessment in basketball (Escudero, 2000). In our study, results indicated that II-basketball coaches and referees expressed that II-players present limitations to carry out the $92.68 \%$ of the activities presented in the questionnaire. These results can be relevant to orientate the activities that should be assessed in II-players to develop basketball-specific eligibility systems, based on coaches and referees opinion.

Among the performance components analyzed, it was highlighted that offensive individual tactics was the component in which II-players seemed to present higher limitations. These limitations were significantly $(\mathrm{p} \leq 0.05)$ higher than limitations in activities related with technical skills or defensive individual tactics. In addition, these opinions seem to be consistent throughout the different sub-samples in this study (referees and coaches per level of competition) independently to their experience, because no differences were found between any of the sub-groups. Offensive individual tactics is relevant to perform in basketball and requires players to read and to decide fast during the game (Araujo \& Esteves, 2009). A recent study demonstrated that tactics following by adaptive behavior were the most differentiating aspects between II-basketball players and AB-basketball players in opinion of coaches and referees' II-basketball (Polo, Pinilla, Coterón, \& Pérez-Tejero, 2017). Also, participants in that study determinated tactical aspects as distinguish element between an eligible or non-eligible II-basketball player. As Tenenmabum (2003) indicated, decision making is an activity that involves many different cognitive processes so, this fact could explain coaches and referees' opinion about how II influences on this component. These results seem to go in line with Burns (2015), who explained that II-athletes might present higher limitations in those activities with higher cognitive demand.

Results presented by Pérez-Tejero et al. (2015) and Pinilla et al. (2015) showed that II-players seemed to reach lower shooting effectiveness, they committed more turnovers and they made less assists compared with AB-players in the literature. Probably, differences in these variables might be explained by a negative influence of II on offensive individual tactics. In line with the results presented by Pinilla et al. (2016), II-players could make decisions as accurate as ABplayers; however, II-players required more time. Regarding these results and the results from this study, it seems that processing speed ability might be negatively influenced by II and could generate negative consequences on players' capacity to carry out fundamental basketball activities related with offensive individual tactics.

Activities related with technical skills received the lowest scores and the mean value was slightly higher than 4 . It seems that these activities can be somewhat difficult but not as much as others. Previous studies found that technical skills development maintained a significant relationship with IQ score of II-basketball players (Franciosi et al. 2012). In our study, it was observed that INAS' coaches punctuated this component below 4 and coaches from lower-level competitions punctuated it over 4; however, no significant relationship was observed between the level of competition and difficulty expressed by coaches' in the different components. 
Probably, the sample of each sub-group in this study is not enough to determine statistical significance but, what it seems relevant is that in high level II-players, II does not seem to have a negative effect on technical components of basketball.

For motor and skills component, Van de Vliet, Rintala, Fröjd, Verellen, Van Houtte, Daly, \& Vanlandewijck (2006) concluded that high-performance II-athletes reached physical fitness levels equal or lower than those of able-bodied sportive counterparts. However, in the present study, coaches and referees indicated that II influenced negatively on several fitness components. This suggests that this relationship should be investigated in future researches. Also, limitations were mentioned regarding activities related with high eye-hand coordination involvement, so ball handling skills, and even shooting, may be negatively influenced by II. These facts could explain the greater number of turnovers and the lower shooting effectiveness compared with results from AB-literature (Pérez et al. 2015) from coaches and referees' opinion.

With regard to the contextual factors, coaches and referees did not consider that II-players present difficulties in social interactions with the team's members (item 1 for this component, see Table 7), but they referred that II-players present limitations in the rest of the contextual situations, as all of the rest items obtained an mean score above 4. Team sports can help IIathletes to increase his self-esteem and can be fundamental for socialization and cooperation with other people who live with the same disability (Guidetti et al. 2007). From this section, it is interesting to observe that coaches and referees presented a high agreement with the affirmation that II-players with higher cognitive abilities obtain better game-statistics and that they reach better fitness levels (item 4, Table 7). This fact seems to confirm that cognitive abilities are relevant to perform in basketball. In addition, differences in cognitive abilities could explain the higher performance variability found between II-players at the same competition when compared with AB-players (Pinilla et al. 2015). Finally coaches and referees consider that II-players present difficulties to adapt themselves to a new and unknown game situation (adaptive behavior). Previous studies found that the learning process in II-athletes had significantly lower levels compared with AB-athletes (Van Biesen et al. 2012), but, at the moment, this learning processes in II basketball is still unknown.

\section{Conclusion}

The purpose of this study was to analyze II-basketball coaches and referees' opinion about how II impact on fundamental basketball activities. The findings of this study indicated that most of the performance components in basketball were negatively affected by II. Offensive individual tactics was highlighted by coaches and referees to be the component in which II-athletes present more limitations. These results are relevant to orientate future research to develop II-basketball eligibility systems, which is a need to re-include this sport in the Paralympic Program.

\section{Acknowledgements}

This project has been subsidized by the Spanish Ministry of Economy, reference number DEP2012-33649.

(c) Psy, Soc, \& Educ, 2017, Vol. 9(3) 


\section{References}

Allard F., Graham S; \& Paarsalu M. (1980). Perception in sport: Basketball. Journal of Sport Psychology, 2, 14-21.

Alsasua R. (2012). Análisis observacional de la construcción de las secuencias ofensivas que acaban en lanzamiento en baloncesto de categoría infantil. Universidad de la Rioja.

Araujo D; \& Esteves P. (2009). The irreducible variability of decision making in basketball. In A. Lorenzo, S. Ibáñez \& E. Ortega (Eds.), Aportaciones Teóricas y Prácticas para el Baloncesto del Futuro (pp. 171-181): Wanceulen.

Burns J. (2015). The impact of intellectual disabilities on elite sports performance. International Review of Sport and Exercise Psychology, 8(1), 251-267.

Franciosi E., Gallotta M.C., Baldari C., Emerenziani G.P; \& Guidetti L. (2012). Basketball ability testing and category for players with mental retardation: 8-month training effect. Journal of Strength and Conditioning Research, 26(6), 1524-1531.

García de Yébenes M.J; Rodríguez Salvanés F; \& Carmona L. (2009). Validation of questionnaires. Reumatología Clínica (English Edition), 5(4), 171-177.

Guidetti L., Franciosi E., Emerenziani G.P., Gallotta M.C; \& Baldari, C. (2007). Assessing basketball ability in players with mental retardation. British Journal of Sports Medicine, 43(3), 208-212. doi: 10.1136/bjsm.2006.034918.

INAS (2015). INAS Annual reports. International Federation for Para-athletes with Intellectual Disabilities. [Retrieved on $27^{\text {th }}$ June 2016 from www.inas.org ].

Escudero J.T.; Balagué G; \& García-Mas A. (2002). Comportamientos que influyen en el rendimiento deportivo de jugadores de baloncesto desde el punto de vista de los entrenadores. Psicothema, 14(1), 34-38.

Martín Arribas M.C. (2004). Diseño y validación de cuestionarios. Matronas Prof., 5(17), 23-29.

Nuno L., Vaz V., Maçãs V; \& Sampaio J. (2009). Coaches perceived importance of drills items in basketball players' long term development. Revista de Psicología del Deporte, 18(3), 457-461.

Ortega E., Salado J; \& Sainz de Baranda P. (2013). Opinión de los entrenadores de baloncesto sobre los sistemas de juego en las distintas categorías en etapas de formación. Kronos, 11(2), 45-53.

Ortega E., Piñar M.I., Salado J., Palao J. M; \& Gómez Ruano M.A. (2012). Opinión de expertos y entrenadores sobre el reglamento de la competición infantil en baloncesto. Revista Internacional de Ciencias del Deporte, 8(28), 142-150.

Ortega E., Salado J., Gómez Ruano M.A., Palao J.M; \& Piñar M.I. (2011). Opinión de los entrenadores y expertos de baloncesto sobre la especialización en puestos específicos. $A D A L, 23,12-16$.

Pérez-Tejero J., Pinilla J; \& Vanlandewijck Y. (2015). Perfil del rendimiento en el campeonato del mundo de baloncesto (Ankara 2013) para personas con discapacidad intelectual: Implicaciones en el sistema de elegibilidad. Revista Iberoamericana de Psicología del Ejercicio y el Deporte, 10(2), 187-192.

Pinilla Arbex, J., Pérez-Tejero, J., \& Van Biesen, D. (2017). Basketball game related statistics that discriminate between players with intellectual impairment and able-bodied players. Revista de Psicología del Deporte, 26(3), 0113-0119. 
Pinilla, J; Pérez-Tejero, J; Van Biesen, D; \& Vanlandewijck, Y. (2016). Effect of Intellectual Impairment on Basketball Game-Related Statistics. Collegium Antropologicum, 40(4), 279-284.

Pinilla J., Pérez-Tejero J., Sampedro J., Refoyo I., Lorenzo A., Lorenzo J; \& Vanlandewijck Y. (2016). Influence of intellectual impairment (II) on basketball players'capacity to solve a game situation: towards evidence-based classification systems in II-basketball. Psychology, Society \& Education, 8(2), 252-265.

Pinilla J., Pérez-Tejero J., Van Biesen D; \& Vanlandewijck Y. (2015). Performance variability in basketball players with intellectual impairment: Ankara World Championships 2013 analysis. Revista de Psicología del Deporte, 24, Suppl 1, 77-83.

Polo, I; Pinilla, J; Coterón, J; \& Pérez-Tejero, J. (2017). Impact of intellectual impairment on basketball performance through coaches and referees' opinion: a qualitative approach. Revista de Psicología del Deporte, 26, 149-155.

Rhodes R.E., Matheson D.H; \& Mark R. (2010). Evaluation of social cognitive scaling response options in the physical activity domain. Measurement in Physical Education and Exercise Science, 14(3), 137-150.

Stanišić Z. (2012). Physical and sport activities of intellectually disabled individuals. Acta Medica Medianae, 51(2), 45-49.

Stanisic Z., Kocic M., Aleksandrovic M., Stankovic M; \& Radovanovic D. (2012). The effects of an adapted basketball training program on the physical fitness of adolescents with mental retardation: a pilot study. Serbian Journal of Experimental and Clinical Research, 13(3), 103-107.

Steadward R.D., Watkinson E.J; \& Wheeler G.D. (2003). Adapted physical activity. Alberta: The University of Alberta Press.

Tenenbaum G. (2003). Expert athletes: an integrated approach to decision making In J. L. Starkes \& K. A. Ericsson (Eds.), Expert Performance in Sports: Advances in Research on Sport Expertise (pp. 191-218). United States of America: Human Kinetics.

Tsimaras V.K., Samara C.A., Kotzamanidou M.C., Bassa E.I., Fotiadou E.G; \& Kotzamanidis C.M. (2009). The effect of basketball training on the muscle strength of adults with mental retardation. J Strength Cond Res, 23(9), 2638-2644.

Tweedy S.M; \& Vanlandewijck Y.C. (2011). International Paralympic Committee position stand - background and scientific principles of classification in Paralympic sport. British Journal of Sports Medicine, 45(4), 259-269.

Van Biesen D., Mactavish J., Pattyn N; \& Vanlandewijck Y. (2012). Technical proficiency among table tennis players with and without intellectual disabilities. Human movement science, 31, 1517-1528.

Van de Vliet P., Rintala P., Fröjd K., Verellen J., Van Houtte S., Daly D. J; \& Vanlandewijck Y.C. (2006). Physical fitness profile of elite athletes with intellectual disability. Scandinavian Journal of Medicine \& Science in Sports, 16(6), 417-425.

Vizcaíno C., Almagro B.J., Rebollo J.A; \& Sáenz-López P., (2013). Coaches' and referees' evaluation of the importance of the rules at the initiation stage of basketball. Revista de Psicología del Deporte, 22 (1), 293-297. 